\title{
Cashew nut-based beverage: development, characteristics and stability during refrigerated storage
}

\author{
Janice Ribeiro LIMA ${ }^{1 *}$ (i), Laura Maria BRUNO², Nedio Jair WURLITZER², \\ Paulo Henrique Machado de SOUSA ${ }^{3}$, Samara Alves de Mesquita HOLANDA ${ }^{3}$
}

\begin{abstract}
A cashew nut-based beverage was obtained using broken cashew kernels and its composition and stability were evaluated during refrigerated storage for 60 days. Sensory tests were performed to define the formulation, testing the best proportion between kernels and water, the effect of kernel roasting, the ideal sweetness, the beverage attributes and the sensory acceptance. A cashew nut beverage can be obtained by grinding the kernel with water in the proportion of $1: 10(\mathrm{~m} / \mathrm{m})$ with added sugar at $3 \%$, followed by heat treatment at $140^{\circ} \mathrm{C}$ for four seconds. The proximate composition was $11.49 \%$ total solids, $0.26 \%$ ashes, $1.83 \%$ proteins, $3.97 \%$ lipids and $5.43 \%$ total carbohydrates. The $\mathrm{pH}$ remained above 6.49 and the color darkened during storage. The product was considered microbiologically safe and shelf-stable for at least 2 months, and sensory acceptance remained at an average value of 7.1 on a 9-point hedonic scale.
\end{abstract}

Keywords: Anacardium occidentale L.; cashew kernel; dairy substitute; nut milk.

Practical Application: Broken cashew nuts used to obtain a beverage which is similar to milk in appearance.

\section{Introduction}

Plant-based beverages were consumed in early civilizations all over the world. Soy-based products are traditional in the Asian diet and are still the most popular cow milk alternative, although products based on other plant materials such as cereals and nuts are also available (Jeske et al., 2017, 2018).

On the other hand, cashew nuts are one of the most important edible nuts in international trade and its commercial processing yields up to $40 \%$ of broken kernels (Lima et al., 2017). Cashew nut-based beverage production from broken kernels, which are considered as by-products, is an alternative to enhance its economic value.

Nut kernels can be important sources of protein and bioactive compounds for vegetable-based diets. Cashew nut kernels present high protein levels (23\%), with all the essential amino acids for humans (Freitas et al., 2012). They also present high levels of lipids (44\%), with mono and polyunsaturated fatty acids being the major components among them (Adjepong et al., 2017).

Nut-based milk substitutes are water soluble extracts which resemble milk in appearance. These products are used to replace milk in the diet due to consumer preference or necessity (lactose intolerance or milk protein allergy). The steps to obtain nut-based milk are usually disintegrating the material in water, removing the solids, formulating the product, and then homogenization and heat treatment (Mäkinen et al., 2015). Milk obtained from brazil nuts (Cardarelli \& Oliveira, 2000; Felberg et al., 2004, 2009), almond nuts (Bernat et al., 2014) and babassu (Carneiro et al.,
2014) have been reported. Prebiotic beverages made from cashew nut kernels, passion fruit juice and mango juice have also been reported (Rebouças et al., 2014, 2016).

Thus, the objective of this work was to develop a beverage from broken cashew nut kernels in order to characterize the beverage and to evaluate its stability during storage under refrigeration.

\section{Materials and methods}

\subsection{Ingredients and beverage processing}

Broken cashew nut kernels (butts, splits and pieces) were obtained from a local supplier in Fortaleza city, Northeastern region of Brazil. Refined cane sugar was purchased in the local market. Kernels were crushed with water and sugar in a colloid mill (Meteor Rex Inox I-V-N, São Paulo, Brazil) for 4 minutes. The beverage was heat treated $\left(140^{\circ} \mathrm{C}, 4 \mathrm{~s}\right)$ in a tubular heat exchanger (Armfield FT74, Ringwood, England) and filled into $210 \mathrm{~mL}$ glass bottles closed with plastic caps.

\subsection{Sensory tests to obtain the beverage formulation}

Five consecutive sensory tests were performed to achieve: the best proportion between kernels and water; the effect of kernel roasting; the ideal sweetness; the attribute diagnostics and the sensory acceptance. Judges were chosen among non-smokers and those who consumed milk regularly. Samples were placed in plastic cups $(30 \mathrm{~mL})$ coded with three digit random numbers 
and presented at refrigerated temperature $\left(\sim 10^{\circ} \mathrm{C}\right)$ in balanced order. Judges were instructed to consume the sample and rinse their mouth with water (room temperature) between sample evaluations. Tests were performed in individual booths under air conditioning at $\left(24^{\circ} \mathrm{C}\right)$ (Meilgaard et al., 2006). The protocols of the sensorial tests were previously approved by the Research Ethics Committee of the Ceará State University (No. 147.279).

A ranking test was initially performed to verify the preference among three formulations with different kernel to water proportions (1:8, 1:10 and $1: 12$ by weight). Thirty (30) judges were asked to rank the samples from less preferred (no. 1) to most preferred (no. 3), and the results were then analyzed by the Friedman test using Newell \& MacFarlane (1987) tables.

Next, a paired preference test was applied to 40 judges to verify whether the beverage made with roasted kernels was preferred over the beverage made with unroasted kernels. Beverages were prepared using a kernel to water proportion of 1:8. The judges' had to make a single choice, and a "no preference" option was not allowed. The number of agreeing responses citing one sample was counted and analyzed using the table for critical number of correct responses in a two sided directional difference test $(\alpha=0.05)$ (Meilgaard et al., 2006).

Thirdly, a "just about right" test was performed to verify the ideal beverage sweetness. Beverages were prepared using a kernel to water proportion of 1:10. Fifty-two (52) judges were asked to evaluate how samples formulated with different sugar contents $(1,2$, and $3 \%)$ were close to the ideal sweetness on a scale ranging from -4 (not at all sweet enough) to +4 (much too sweet). The results were grouped in below ideal ( -4 to -1 values), ideal ( 0 value) and above ideal (1 to 4 values), and presented as a frequency histogram (Meilgaard et al., 2006).

In the fourth stage, an attribute diagnostic was conducted with 30 judges in order to evaluate the intensity of some attributes in the beverage: white color (light to dark), gray color (light to dark), homogeneity (few to much), nut flavor (weak to strong), body (thin to thick) and particle presence in the mouth (few to much). Judges were asked to evaluate the intensity of each attribute using $9 \mathrm{~cm}$ scales. The results were presented as means (Meilgaard et al., 2006). The attributes were selected upon literature (Felberg et al., 2009; Jeske et al., 2018; Mäkinen et al., 2015).

Finally, an acceptance test was performed in order to evaluate how well the beverage developed in the previous tests is liked by the consumers. One hundred (100) judges evaluated the beverage using a 9-point hedonic structured scale, on which 1 was 'extremely dislike', and 9 was 'extremely like' for the overall acceptability. Judges were also asked about their purchase intent using a 5-point structured scale ranging from 1 (I certainly wouldn't buy it) to 5 (I certainly would buy it). The results were presented as mean values and frequency of each sensory category (Meilgaard et al., 2006).

\subsection{Physicochemical analysis of the cashew kernel beverage}

The obtained beverage as defined by the sensory tests was analyzed for $\mathrm{pH}$ and solids, ash, lipid and protein contents (Instituto Adolfo Lutz, 2008). Total carbohydrate content was estimated by the difference from other components using the formula: 100 - [weight in grams (protein + lipids + ash)] in $100 \mathrm{~g}$ of the beverage. The energy value was calculated using $4 \mathrm{kcal} / \mathrm{g}$ for carbohydrates and proteins and $9 \mathrm{kcal} / \mathrm{g}$ for lipids (Merril \& Watt, 1973). The analyses were performed in four repetitions and the results presented as means and standard deviations.

\subsection{Storage stability of the cashew kernel beverage}

The obtained beverage as defined by the sensory tests was prepared, heat-treated and filled in glass bottles $(210 \mathrm{~mL})$ closed with plastic screw caps. The stability test $(\mathrm{pH}$, color, sensory acceptance and microbiological quality) was carried out at refrigerated temperature $\left(5 \pm 2{ }^{\circ} \mathrm{C}\right)$ in 20 day intervals up to 60 days. The $\mathrm{pH}$ and sensory acceptance were performed as previously described. The sensory tests were performed with 50 judges at each analysis time. The color was assessed using a colorimeter (Chroma Meter CR-400, Konica Minolta Sensing Inc., Osaka, Japan) to determine the $L^{*} a^{*} b^{*}$ values, using D65 illuminant and the whiteness index was calculated using the formula: $\mathrm{WI}=100-\left[\left(100-\mathrm{L}^{*}\right)^{2}+\left(\mathrm{a}^{\star}\right)^{2}+\left(\mathrm{b}^{\star}\right)^{2}\right]^{1 / 2}$. The analyses were performed in four repetitions.

The results of $\mathrm{pH}$, color and sensory acceptance were submitted to variance analysis using the SAS statistical program for Windows system (SAS Institute, 2009), and were compared with the Tukey test $(\alpha=0.05)$ when significant.

The microbiological quality of the samples was analyzed by determining: mesophilic aerobes; total and fecal coliforms; total counts of molds and yeasts, Staphylococcus aureus and Salmonella sp, according to the Bacteriological Analytical Manual Guidelines (Food and Drug Administration, 1998). The analyses were performed in three repetitions.

\section{Results and discussion}

\subsection{Kernel to water proportion}

The formulation with the higher kernel amount (1:8) was preferred over the formulation with the lower amount (1:12), but it did not differ from the one prepared with 1:10 ratio of kernel to water (Table 1). Thus, the 1:10 formulation was chosen for the beverage preparation due to the higher yield since the product concentration is smaller. The proportion between kernels to water in nut-based milks in literature reports range from 1:6 up to 1:12 (Bernat et al., 2014; Dhakal et al., 2014; Felberg et al., 2009; Rebouças et al., 2014).

\subsection{Roasted versus unroasted nut kernels}

The minimum number of agreeing answers to establish significance $(n=40, a=0.05)$ for the paired preference test applied to verify whether the beverage made with roasted kernels

Table 1. Ranking scores for cashew nut beverages with different kernel and water proportions $(\mathrm{n}=30)$.

\begin{tabular}{cccc}
\hline Kernel:water proportion & $1: 8$ & $1: 10$ & $1: 12$ \\
\hline Ranking scores & $70^{\mathrm{a}}$ & $61^{\mathrm{ab}}$ & $49^{\mathrm{b}}$ \\
\hline
\end{tabular}

Means with the same letters are not statistically different (Friedman, $\alpha=0.05$ ). 
was preferred over the beverage made with unroasted kernels is 29 . The number of judges who preferred the beverage with unroasted kernels was 15 , while the number who preferred the beverage made with roasted kernels was 25 (difference $=10$ ), thus indicating no preference between the samples. Thus, considering that roasting may have a negative effect on the vitamin content (Stuetz et al., 2017) and that sensory tests indicate no need for roasting the kernels to obtain the beverage, unroasted kernels were preferred for preparing the beverage. This enabled avoiding one process step and saving energy in the preparation process.

\subsection{Sugar content}

The "just about right" test showed that the majority (59.6\%) of the judges found 3\% sugar as the ideal sweetness (Figure 1). This was also the sugar concentration used by Felberg et al. (2009) to obtain a soy and brazil nut beverage, and by Rebouças et al. (2014) to obtain a beverage from cashew nut kernels and passion fruit juice.

\subsection{Attribute diagnosis}

Consumers rated the white color, nut flavor, homogeneity and body in the middle of the scales (Figure 2). A low quality of cashew kernels is usually related to brown color and black spots in the kernels due to fungi or diseases (Sunoj et al., 2018), which gives a gray coloration to nut-based milks. Therefore, the small value observed for gray color (1.6) shows that although the kernels used for the formulation were broken, they still had good quality. Mouth particles also received small value (2.5), which is a good result since large insoluble particles can produce a chalky mouth feeling (Durand et al., 2003).

\subsection{Sensory acceptance and purchase intent}

The mean of the hedonic values for the sensory acceptance test was 6.5 , which was between the categories "like slightly" and "like moderately". Seventy-five percent (75\%) of the hedonic sensory scores (Figure 3 ) were within the acceptance range of the scale, which comprises categories from 6 (like slightly) to 9 (like extremely). Therefore, it can be concluded that the beverage was accepted by the consumers. When asked about the purchase intent (Figure 4), 38\% of the judges answered that they would probably buy it or certainly would buy it, while $26 \%$ were not sure about buying it. Mäkinen et al. (2015) evaluated the sensory response of commercial UHT-treated lactose free bovine, soy, oat, quinoa and rice milks using a 9-point hedonic scale and obtained values ranging from 3.2 to 5.9 for overall acceptance, which are much lower than the values obtained in our study. However, performing additional sensory tests as projective methods would be advisable (Soares et al., 2020) as well as innovative methods based in consumer perception (Judacewski et al., 2019).

\subsection{Physicochemical characteristics}

The Proximate composition of the beverage was $11.49 \%$ $( \pm 0.08)$ total solids, $0.26 \%( \pm 0.00)$ ashes, $1.83 \%( \pm 0.03)$ proteins, $3.97 \%( \pm 0.07)$ lipids and $5.43 \%( \pm 0.12)$ total carbohydrates. The $\mathrm{pH}$ was $6.49( \pm 0.00)$ and the energy value was

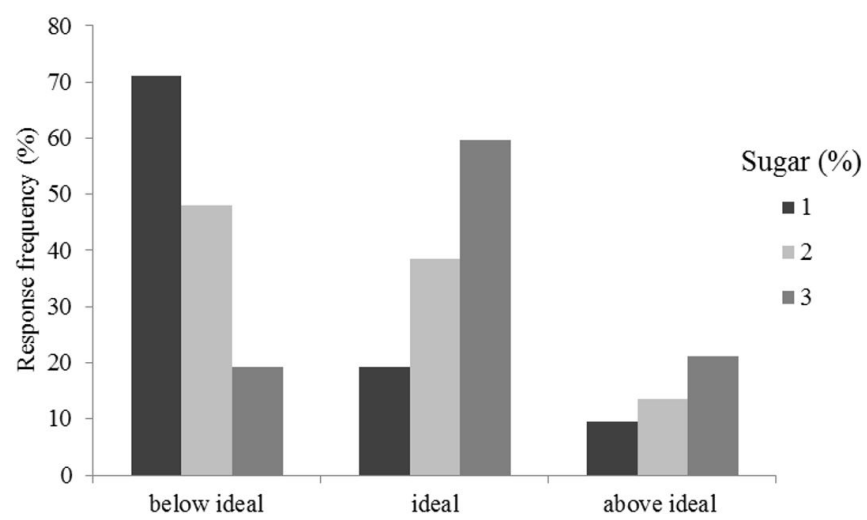

Figure 1. Sensory response for cashew nut beverage sweetness $(n=52)$.

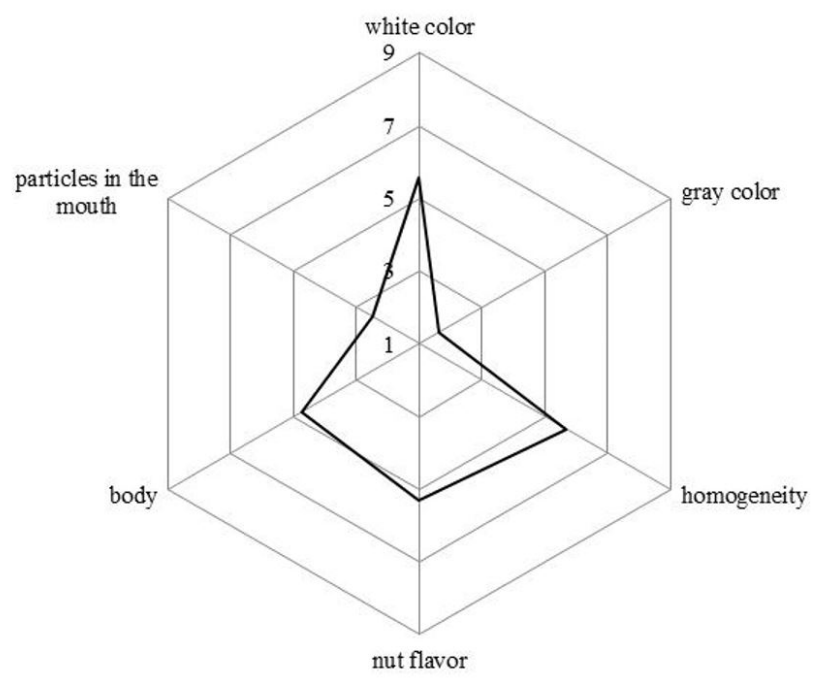

Figure 2. Attributes for cashew nut beverage $(\mathrm{n}=30)$.



Figure 3. Sensory acceptance of cashew nut beverage $(\mathrm{n}=100)$.

$64.73( \pm 0.36) \mathrm{Kcal} / 100 \mathrm{~mL}$. Jeske et al. (2017) reported the physicochemical properties of 17 different commercial plant-based milk substitutes. These authors reported lower values for protein $(0.87 \%)$ and lipids $(2.50 \%)$ for a cashew nut drink than the values obtained in our study, and found out that half of the analyzed samples had low or no protein contents $(<0.5 \%)$. However, they also stated that nutritional and physicochemical properties are strongly dependent on the plant source, processing and fortification. The cashew nut kernel beverage developed in 


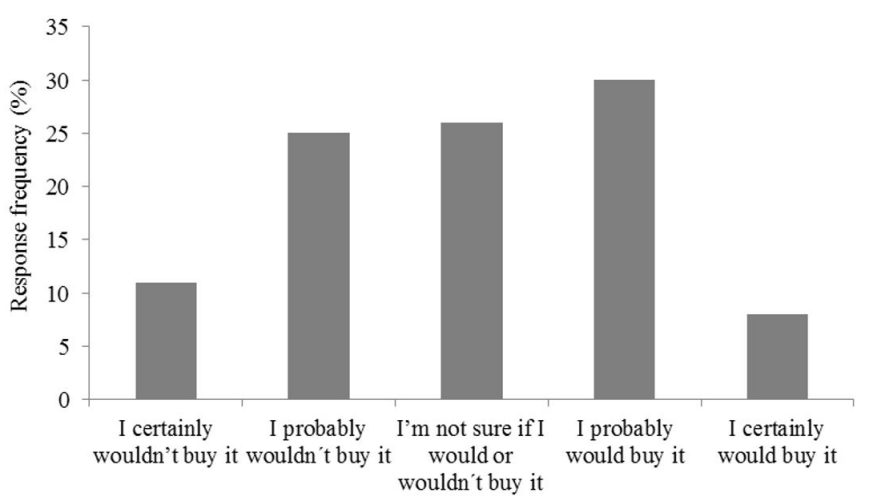

Figure 4. Purchase intent of cashew nut beverage $(n=100)$.

Table 2. Characteristics of cashew nut beverage during refrigerated storage $\left(5 \pm 2{ }^{\circ} \mathrm{C}\right)$ (mean \pm standard deviation).

\begin{tabular}{cccc}
\hline Time (days) & $\mathrm{pH}$ & $\begin{array}{c}\text { Whiteness } \\
\text { index }\end{array}$ & $\begin{array}{c}\text { Sensory } \\
\text { acceptance }\end{array}$ \\
\hline 0 & $6.5 \pm 0.0^{\mathrm{c}}$ & $84.2 \pm 0.2^{\mathrm{a}}$ & $6.9 \pm 1.5^{\mathrm{a}}$ \\
20 & $6.7 \pm 0.0^{\mathrm{a}}$ & $84.2 \pm 0.1^{\mathrm{a}}$ & $7.0 \pm 1.7^{\mathrm{a}}$ \\
40 & $6.6 \pm 0.0^{\mathrm{b}}$ & $83.9 \pm 0.1^{\mathrm{b}}$ & $7.3 \pm 1.6^{\mathrm{a}}$ \\
60 & $6.6 \pm 0.0^{\mathrm{b}}$ & $83.7 \pm 0.1^{\mathrm{b}}$ & $7.3 \pm 1.7^{\mathrm{a}}$ \\
\hline
\end{tabular}

Means with the same letters are not statistically different in the columns (Tukey, $a=0.05$ ).

our study had half the protein content and almost the same fat content when compared to cow's milk, which has $3.70 \%$ of proteins and $3.28 \%$ of lipids (Jeske et al., 2017).

\subsection{Stability during refrigerated storage}

The $\mathrm{pH}$ remained above 6.49 , which is an indication that the heat treatment was efficient and no acid production micro-organisms were grown (Table 2). This was confirmed since the most probable numbers (MPN) of all coliforms including Escherichia coli were lower than 3 organisms per $\mathrm{mL}$, Salmonella spp. was absent in $25 \mathrm{~g}$, Staphylococcus were lower than $10 \mathrm{CFU} / \mathrm{mL}$, and yeasts and molds were lower than $10^{3} \mathrm{CFU} / \mathrm{mL}$ throughout the 60 days of refrigerated storage. The mesophilic aerobe count was at $10^{3}$, which did not present any health hazard. Thus, the beverage was considered microbiologically safe and shelf-stable for at least 60 days.

There were significant differences observed in the whiteness index during the storage time, which showed that the cashew nut kernel beverage was becoming darker. The whiteness index is one of the most important quality parameters for milk, and despite the observed decrease, the values stayed close to the value of 81.89 reported for bovine milk (Jeske et al., 2017).

\section{Conclusions}

The cashew nut beverage can be obtained by grinding the unroasted kernel with water in the proportion of 1:10 with sugar added at $3 \%$, followed by heat treatment at $140{ }^{\circ} \mathrm{C}$ for four seconds. The beverage shows physicochemical and microbiological stability, as well as good sensory acceptance for 60 days of refrigerated storage, therefore constituting an interesting use for the nut processing by-product.

\section{References}

Adjepong, M., Valentini, K., Pickens, C. A., Li, W., Appaw, W., \& Fenton, J. (2017). Quantification of fatty acid and mineral levels of selected seeds, nuts, and oils in Ghana. Journal of Food Composition and Analysis, 59, 43-49. http://dx.doi.org/10.1016/j.jfca.2017.02.007.

Bernat, N., Cháfer, M., Chiralt, A., \& González-Martinez, C. (2014). Development of a non-dairy probiotic fermented product based on almond milk and inulin. Food Science \& Technology International, 21(6), 440-453. http://dx.doi.org/10.1177/1082013214543705. PMid:25028153.

Cardarelli, H. R., \& Oliveira, A. J. (2000). Conservação do leite de castanha-do-pará. Scientia Agrícola, 57(4), 617-622. http://dx.doi. org/10.1590/S0103-90162000000400004.

Carneiro, B. L. A., Arévalo-Pinedo, A., Scartazzini, L., Zuniga, A. D. G., \& Pinedo, R. A. (2014). Estudo da estabilidade do extrato hidrossolúvel "leite" de babaçu (Orbygnia speciosa) pasteurizado e armazenado sob refrigeração. Revista Brasileira de Fruticultura, 36(1), 232-236. http://dx.doi.org/10.1590/0100-2945-334/13.

Dhakal, S., Liu, C., Zhang, Y., Roux, K. H., Sathe, S. K., \& Balasubramaniam, V.M. (2014). Effect of high pressure processing on the immunoreactivity of almond milk. Food Research International, 62, 215-222. http:// dx.doi.org/10.1016/j.foodres.2014.02.021.

Durand, A., Franks, G. V., \& Hosken, R. W. (2003). Particle sizes and stability of UHT bovine, cereal and grain milks. Food Hydrocolloids, 17(5), 671-678. http://dx.doi.org/10.1016/S0268-005X(03)00012-2.

Felberg, I., Antoniassi, R., Deliza, R., Freitas, S. C., \& Modesta, R. C. (2009). Soy and brazil nut beverage: processing, composition, sensory and color evaluation. Food Science and Technology (Campinas), 29(3), 609-617. http://dx.doi.org/10.1590/S0101-20612009000300024.

Felberg, I., Deliza, R., Gonçalves, E. B., Antoniassi, R., Freitas, S. C., \& Cabral, L. C. (2004). Bebida mista de extrato de soja integral e castanha-do-brasil: caracterização físico-química, nutricional e aceitabilidade do consumidor. Alimentos e Nutrição, 15, 163-174.

Food and Drug Administration - FAO. (1998). Bacteriological analytical manual. Geneva: FAO. Retrieved from http://www.fda.gov/Food/ FoodScienceResearch/LaboratoryMethods/ucm2006949.htm

Freitas, J. B., Fernandes, D. C., Czeder, L. P., Lima, J. C. R., Sousa, A. G. O., \& Naves, M. M. V. (2012). Edible seeds and nuts grown in Brazil as sources of protein for human nutrition. Food and Nutrition Sciences, 3(06), 857-862. http://dx.doi.org/10.4236/fns.2012.36114.

Instituto Adolfo Lutz - IAL. (2008). Normas Analíticas do Instituto Adolfo Lutz: métodos físico-químicos para análise de alimentos. São Paulo: IAL.

Jeske, S., Zannini, E., \& Arendt, E. K. (2017). Evaluation of physicochemical and glycaemic properties of commercial plant-based milk substitutes. Plant Foods for Human Nutrition (Dordrecht, Netherlands), 72(1), 26-33. http://dx.doi.org/10.1007/s11130-016-0583-0. PMid:27817089.

Jeske, S., Zannini, E., \& Arendt, E. K. (2018). Past, present and future: The strength of plant-based dairy substitutes based on gluten-free raw materials. Food Research International, 110, 42-51. http://dx.doi. org/10.1016/j.foodres.2017.03.045. PMid:30029705.

Judacewski, P., Los, P. R., Lima, L. S., Alberti, A., Zielinski, A. A. F., \& Nogueira, A. (2019). Perceptions of brazilian consumers regarding white mould surface-ripened cheese using free word association. International Journal of Dairy Technology, 72(4), 585-590. http:// dx.doi.org/10.1111/1471-0307.12649.

Lima, J. R., Garruti, D. S., Bruno, L. M., Araujo, I. M. S., Nobre, A. C. O., \& Garcia, L. G. S. (2017). Replacement of peanut by residue from the cashew nut kernel oil extraction to produce a type paçoca candy. Journal of Food Processing and Preservation, 41(2), e12775. http://dx.doi.org/10.1111/jfpp.12775. 
Mäkinen, O. E., Uniacke-Lowe, T., O’Mahony, J. A., \& Arendt, E. K. (2015). Physicochemical and acid gelation properties of commercial UHT-treated plant-based milk substitutes and lactose free bovine milk. Food Chemistry, 168, 630-638. http://dx.doi.org/10.1016/j. foodchem.2014.07.036. PMid:25172757.

Meilgaard, M. C., Carr, B. T., \& Carr, B. T. (2006). Sensory evaluation techniques (464 p.). New York, USA: CRC Press. http://dx.doi. org/10.1201/b16452.

Merril, A. L., \& Watt, B. K. (1973). Energy value of foods: basis and derivation (Vol. 74, Agriculture handbook). Washington: United States Department of Agriculture.

Newell, G. J., \& MacFarlane, J. D. (1987). Expanded tables for multiple comparison procedures in the analysis of ranked data. Journal of Food Science, 52(6), 1721-1725. http://dx.doi.org/10.1111/j.1365-2621.1987. tb05913.x.

Rebouças, M. C., Rodrigues, M. C. P., \& Afonso, M. R. A. (2014). Optimization of the acceptance of prebiotic beverage made from cashew nut kernels and passion fruit juice. Journal of Food Science, 79(7), S1393-S1398. http://dx.doi.org/10.1111/1750-3841.12507. PMid:24961964.
Rebouças, M. C., Rodrigues, M. C. P., Freitas, S. M., \& Ferreira, B. B. A. (2016). The physicochemical optimization and acceptability of a cashew nut-based beverage varying in mango juice and sugar: a pilot study. Beverages, 2(3), 23. http://dx.doi.org/10.3390/beverages2030023.

SAS Institute. (2009). Statistical analysis system (SAS) user's guide. Cary, NC: SAS Institute.

Soares, E. K. B., Silva, R., Silva, W. P., Kuriya, S. P., Maçaira, P. M., Cyrino Oliveira, F. L., Silva, M. A. A. P., Pimentel, T. C., Freitas, M. Q., Cruz, A. G., \& Esmerino, E. A. (2020). An intra-cultural investigation in Brazil using Coalho cheese and preferred attribute elicitation. Journal of Sensory Studies, 35(1), e12543. http://dx.doi. org/10.1111/joss.12543.

Stuetz, W., Schlörmann, W., \& Glei, M. (2017). B-vitamins and $\alpha-/ \gamma$ tocopherol in raw and roasted nuts. Food Chemistry, 221, 222-227. http://dx.doi.org/10.1016/j.foodchem.2016.10.065. PMid:27979196.

Sunoj, S., Igathinathane, C., \& Jenicka, S. (2018). Cashews whole and splits classification using a novel machine vision approach. Postharvest Biology and Technology, 138, 19-30. http://dx.doi.org/10.1016/j. postharvbio.2017.12.006. 